\title{
Pengembangan Penuntun Praktikum Kimia Berorientasi chemoentrepreneurship untuk SMA/MA Kelas XII Semester Ganjil
}

\author{
Hutdia Putri Murni ${ }^{1}$, Latisma $\mathrm{Dj}^{2}$, Rahadian Zainul ${ }^{3}$ \\ ${ }^{1}$ Jurusan Kimia, Universitas Negeri Padang, Padang, Indonesia, $\square$ hutdiaputri.hp@gmail.com \\ 2Jurusan Kimia, Universitas Negeri Padang, Padang, Indonesia, $\square$ latismadj@gmail.com \\ 3Jurusan Kimia, Universitas Negeri Padang, Padang, Indonesia, $\square$ rahadianzmsiphd@gmail.com
}

\begin{abstract}
Abstrak
Penuntun praktikum berorientasi chemoentrepreneurship (CEP) merupakan pedoman pelaksanaan praktikum yang memungkinkan siswa dapat mempelajari proses pengolahan suatu bahan menjadi produk yang bermanfaat, bernilai ekonomis sehingga dapat menumbuhkan semangat berwirausaha siswa. Pengembangan penuntun praktikum ini menggunakan pendekatan kontekstual yang dikaitkan langsung dengan fenomena di sekitar kehidupan siswa. Penelitian ini bertujuan untuk menghasilkan sebuah penuntun praktikum berorientasi CEP yang kemudian diuji kevalidan dan kepraktisannya. Jenis penelitian yang digunakan adalah Research and Development $(R \& D)$, dengan model 4-D yang terdiri dari tahap define, design, develop, dan disseminate. Validasi dilakukan oleh 5 orang validator dan dinilai kepraktisannya oleh 2 orang guru kimia SMA dan 27 orang siswa kelas XII IPA SMA N 12 Padang tahun ajaran 2016/2017. Hasil analisis uji validitas diperoleh momen kappa sebesar 0,88 dengan kategori kevalidan sangat tinggi. Hasil uji praktikalitas berdasarkan angket respon guru dan siswa diperoleh nilai momen kappa sebesar 0,82 yang berada pada kategori sangat tinggi. Berdasarkan hasil tersebut, dapat disimpulkan bahwa, penuntun praktikum berorientasi Chemoentrepreneurship yang dihasilkan telah valid dan praktis digunakan dalam proses praktikum kimia.
\end{abstract}

Kata kunci : pengembangan, penuntun praktikum, chemoentrepreneurship, 4-D models

\section{Pendahuluan}

Perkembangan di bidang pendidikan pada hakikatnya bertujuan untuk mencerdaskan dan meningkatkan kualitas sumber daya manusia sehingga dapat memiliki kehidupan yang layak ${ }^{[1]}$, termasuk pada tingkat pendidikan Sekolah Menengah Atas (SMA). SMA adalah jenjang pendidikan yang mempersiapkan peserta didiknya untuk melanjutkan ke perguruan tinggi. Anies Baswedan ${ }^{[2]}$ menjelaskan bahwa jumlah yang bisa melanjutkan studi hanya 60 persen, sedangkan yang tidak bisa melanjutkan studi ke jenjang perguruan tinggi memilih untuk bekerja. Namun, hal itu pun tak mudah karena lulusan SMA selama ini dianggap tidak memiliki keterampilan sehingga menjadi pengangguran. Menurut Badan Pusat Statistik (BPS) tahun 2016 ${ }^{[3]}$, pengangguran dari lulusan SMA menempati urutan ketiga dengan persentase Tingkat Pengangguran Terbuka (TPT) sebesar 6,95 persen dari total pengangguran 7,02 juta orang. Berdasarkan data tersebut maka diperlukan adanya upaya untuk mempersiapkan peserta didik SMA menjadi lulusan berkualitas dan memiliki keterampilan sehingga mampu memenuhi lapangan kerja di Indonesia.

Langkah awal yang dapat dilakukan untuk mengatasi masalah pengangguran tersebut adalah menumbuhkan minat kewirausahaan sedini mungkin. Berdasarkan Inpres No.4 Tahun 1995, perlu dibudayakan semangat, sikap, perilaku dan kemampuan kewirausahaan di kalangan masyarakat terutama pada generasi muda ${ }^{[4]}$. Dengan begitu, peserta didik lulusan SMA yang tidak dapat melanjutkan ke perguruan tinggi dapat bekerja secara mandiri dengan semangat dan kreativitas yang dimilikinya tanpa bergantung pada orang lain.

Kebutuhan akan orientasi baru dalam pendidikan terasa begitu kuat dan nyata di berbagai bidang studi yang menuntut lulusannya memiliki suatu skill, demikian pula dalam bidang studi kimia ${ }^{[5]}$. American Chemical Society menyatakan bahwa kimia merupakan laboratory science yang berarti, bahwa pembelajaran kimia tidak akan efektif tanpa melakukan pengalaman laboratorium (eksperimen/praktikum) ${ }^{[6]}$. Pelaksanaan praktikum di laboratorium membutuhkan penuntun praktikum yang merupakan pedoman pelaksanaan yang digunakan dalam melakukan kegiatan praktikum ${ }^{[7]}$. Salah satu pendekatan yang dapat diintegrasikan dalam penuntun praktikum adalah pendekatan chemoentrepreneurship (CEP). Pendekatan CEP adalah suatu pendekatan pembelajaran kimia yang kontekstual yaitu pendekatan pembelajaran kimia dikaitkan langsung dengan objek nyata atau fenomena di sekitar kehidupan manusia sebagai peserta didik. Pendekatan CEP memungkinkan peserta didik dapat 
mempelajari proses pengolahan suatu bahan menjadi produk yang bermanfaat, bernilai ekonomi dan menumbuhkan semangat wirausaha $^{[8]}$.

Penelitian mengenai penerapan pendekatan chemoentrepreneurship (CEP) yang dilakukan oleh Qudsiyah dkk. ${ }^{[9]}$ memberikan hasil bahwa, "Siswa pada kelas ekperimen menyukai pembelajaran dengan implementasi praktikum aplikatif berorientasi CEP karena lebih menyenangkan, menarik, dan dapat membuat siswa lebih mudah memahami konsep materi, hal ini dapat dilihat dari rasa ingin tahu siswa yang meningkat dalam pembelajaran dan mereka lebih termotivasi untuk giat belajar baik individu maupun kelompok." Dalam penelitian lain Masithoh ${ }^{[10]}$ menyimpulkan bahwa "penuntun praktikum berorientasi chemoentrepreneurship (CEP) efektif untuk menumbuhkan minat wirausaha dan meningkatkan pemahaman konsep peserta didik."

Berdasarkan wawancara dengan tiga orang guru kimia pada SMA yang berbeda di kota Padang diperoleh informasi bahwa pada proses pembelajaran kelas XII semeseter ganjil sudah digunakan metode praktikum untuk membuktikan teori yang dipelajari maupun untuk menemukan konsep. Namun, praktikum yang dilaksanakan belum ditunjang dengan penuntun praktikum yang dapat memaksimalkan kegiatan percobaan peserta didik di laboratorium. Selanjutnya diketahui bahwa praktikum yang dilaksanakan belum sampai pada penerapan atau aplikasi yang menghasilkan produk. Padahal, praktikum yang berorientasi chemoentrepreneurship dapat menumbuhkan semangat berwirausaha dan efektif menambah life skills peserta $\operatorname{didik}^{[11]}$.

Berdasarkan hal diatas, maka perlu dilakukan penelitian untuk mengembangkan bahan ajar dalam bentuk penuntun praktikum berorientasi chemoentrepreneurship dengan judul "Pengembangan Penuntun Praktikum Berorientasi Chemoentrepreneurship untuk SMA/MA Kelas XII".

\section{Metode Penelitian}

Penelitian ini merupakan penelitian dan pengembangan atau Research and Development (R\&D). Subjek penelitian ini adalah 3 orang dosen kimia FMIPA UNP, 2 orang guru kimia dan 27 orang siswa kelas XII IPA 5 SMAN 12 Padang. Objek Penelitian adalah penuntun praktikum berorientasi CEP untuk SMA/MA Kelas XII. Model pengembangan yang digunakan adalah model 4-D (Four D models). Model 4-D terdiri 4 tahap utama, yaitu tahap define (penndefinisian), tahap design (perancangan), tahap develop (pengembangan), dan tahap dessiminate (penyebaran). Namun, pada penelitian ini dibatasi hanya sampai tahap develop karena keterbatasan waktu dan biaya.

Tahap define bertujuan untuk menetapkan dan mendefinisikan syarat-syarat pembelajaran yang diawali dengan analisis tujuan dari materi yang akan dikembangkan berdasarkan kurikulum 2013 revisi 2016. Tahap define ini terdiri dari 5 langkah pokok yaitu: (1) Analisis ujung depan (2) Analisis peserta didik (3) Analisis Tugas (4) Analisis konsep (5) Analisis tujuan pembelajaran.

Tahap design bertujuan untuk menyiapkan produk awal (prototype) atau rancangan produk yang akan dikembangkan. Pada tahap ini rancangan penuntun praktikum berorientasi CEP harus dikerjakan sebelum ujicoba dilakukan. Selanjutnya dilakukan tahap develop (pengembangan), yang terdiri atas dua kegiatan yaitu uji validitas dan uji praktikalitas. Uji validitas dilakukan dengan memberikan angket validitas yang terdiri dari 4 aspek penilaian yaitu segi kelayakan isi, kebahasaan, penyajian, dan kegrafisan kepada 5 orang validator ( 3 orang dosen kimia dan 2 orang guru kimia). Uji praktikalitas diperoleh melalui angket respon guru dan angket respon siswa kelas XII IPA 5 SMAN 12 Padang.

Instrumen pengumpulan data yang digunakan dalam penelitian ini adalah angket validitas dan praktikalitas. Data dari angket validitas dan praktikalias yang diperoleh dianalisis menggunakan formula Kappa cohen untuk menentukan tingkat validitas dan praktikalitas penuntun praktikum berorientasi chemoentrepreneurship melalui interpretasi data momen Kappa seperti yang terlihat pada Tabel I ${ }^{[12]}$.

$$
\text { Momen kappa }(k)=\frac{\rho-\rho e}{1-\rho e}
$$


TABEL I

KATEGORI KEPUTUSAN BERDASARKAN

MOMEN KAPPA $(k)$

\begin{tabular}{|c|c|}
\hline Interval & Kategori \\
\hline $\mathbf{0 , 8 1}-\mathbf{1 , 0 0}$ & sangat tinggi \\
\hline $\mathbf{0 , 6 1}-\mathbf{0 , 8 0}$ & Tinggi \\
\hline $\mathbf{0 , 4 1}-\mathbf{0 , 6 0}$ & Sedang \\
\hline $\mathbf{0 , 2 1}-\mathbf{0 , 4 0}$ & Rendah \\
\hline $\mathbf{0 , 0 1}-\mathbf{0 , 2 0}$ & sangat rendah \\
\hline
\end{tabular}

\section{Hasil dan Diskusi}

\section{A. Hasil Pengembangan}

Berdasarkan tujuan dan jenis penelitian yaitu Research and Development (R\&D) dengan menggunakan model pengembangan 4-D, produk yang dihasilkan ialah berupa penuntun praktikum kimia berorientasi CEP untuk kelas XII SMA/MA. Hasil penelitian secara keseluruhan untuk masing-masing tahapan diuraikan sebagai berikut ini.

1. Tahap Define (Pendefinisian)

Pada tahap pendefinisian ini diperoleh 5 data yaitu analisis ujung depan, analisis siswa, analisis tugas, analisis konsep, dan analisis tujuan pembelajaran.

a. Analisis Ujung Depan

Analisis ujung depan bertujuan untuk memunculkan masalah dasar dan alternatif yang dikembangkan untuk memecahkan masalah tersebut. Pada tahap analisis ujung depan ini, dilakukan analisis terhadap data jumlah lulusan SMA yang bisa meneruskan pendidikan ke perguruan tinggi. Jumlah yang bisa melanjutkan studi hanya 60 persen, sedangkan yang tidak bisa melanjutkan studi memilih untuk bekerja. Berdasarkan Badan Pusat Statistik tahun 2016, jumlah pengangguran di Indonesia pada Februari 2016 mencapai 7,02 juta orang. Pengangguran dari lulusan SMA memiliki persentase Tingkat Pengangguran Terbuka (TPT) sebesar 6,95 persen.

Langkah selanjutnya adalah dilakukan analisis terhadap permasalahan umum yang terjadi dalam pembelajaran kimia, khususnya pembelajaran di laboratorium atau praktikum pada semester ganjil kelas XII IPA SMA. Tahap ini dilaksanakan dengan melakukan wawancara dengan 3 orang guru kimia di kota Padang. Berdasarkan hasil wawancara dengan guru dapat disimpulkan bahwa masalah utama yang terjadi terkait dengan kegiatan pembelajaran di laboratorium (praktikum) di sekolah selama ini keterlaksanaannya belum sesuai dengan tuntutan kurikulum. Sebagian besar guru telah melakukan kegiatan praktikum untuk beberapa materi pembelajaran, namun masih terdapat materi yang belum dipraktikumkan yang disebabkan kendala-kendala tertentu. Selain itu, bahan ajar yang dapat menunjang keberlangsungan kegiatan pembelajaran di laboratorium atau yang disebut penuntun praktikum belum tersedia.

Guru menjelaskan bahwa penuntun praktikum yang digunakan dalam kegiatan percobaan diambil dari LKS, buku paket dan searching melalui internet. Berdasarkan pengalaman guru, pemahaman siswa lebih meningkat bila kegiatan praktikum terlaksana, seperti siswa lebih mudah memahami dan mengingat materi pembelajaran. Selain itu, praktikum yang dilaksanakan di sekolah belum sampai pada penerapan atau aplikasi yang menghasilkan suatu produk ekonomis, artinya belum mengajarkan kegiatan entrepreneurship.

Berdasarkan dua tahap analisis yang telah dilakukan, dibutuhkan suatu bahan ajar yang dapat menunjang keberlangsungan kegiatan praktikum di laboratorium, dapat meningkatkan pemahaman konsep siswa dan dapat memberikan suatu skill atau keterampilan sehingga lulusan SMA dapat bersaing dalam dunia kerja dengan ilmu yang telah dimilikinya. Bahan ajar tersebut adalah penuntun praktikum berorientasi Chemoentrepreneurship. Setelah masalah ditetapkan dilanjutkan pada tahap analisis siswa.

b. Analisis Siswa

Tujuan dari analisis ini dilakukan untuk menelaah karakteristik siswa sebagai gambaran untuk mendesain penuntun praktikum. Analisis yang dilakukan adalah analisis usia. Dalam penelitian ini siswa yang akan dijadikan sebagai subjek penelitian adalah siswa SMA kelas XII yang berusia antara 15-17 tahun. Menurut teori belajar Piaget taraf berfikir anak usia tersebut pada tahapan perkembangan operasional formal. Pada tahap ini anak sudah mampu berpikir abstrak dan logis dengan menggunakan pola pikir "kemungkinan" dan sudah memiliki kemampuan menarik kesimpulan, menafsirkan dan mengembangkan hipotesa ${ }^{[13]}$. Hal ini dijadikan pertimbangan dalam menyusun penuntun praktikum yang dikembangkan.

Berdasarkan hasil pengamatan dalam proses pembelajaran, dapat diketahui secara garis besar karakteristik cara belajar siswa adalah sebagai berikut ini. 
1) Siswa mudah lupa terhadap konsep yang dipelajarinya jika dalam pembelajaran tidak diberikan contoh yang bersifat kontekstual.

2) Siswa menyukai dan antusias dengan kegiatan pembelajaran di laboratorium karena siswa dapat mengamati objek secara langsung.

3) Siswa lebih menyukai bahan ajar yang berwarna. Berdasarkan hasil wawancara dengan siswa, dapat diketahui bahwa tampilan bahan ajar yang kurang menarik (tanpa warna) membuat siswa menjadi bosan untuk mempelajari bahan ajar tersebut. Selanjutnya, warna merupakan salah satu bagian terpenting yang dapat menjadi daya tarik sebuah benda, karya seni atau desain, termasuk bahan ajar. Warna memberikan kesempurnaan dalam sebuah desain $^{[14]}$

Hasil analisis dari karakteristik siswa menjadi pertimbangan dalam pengembangan penuntun praktikum berorientasi Chemoentrepreneurship pada Kelas XII. Pada penuntun praktikum ini, terdapat susunan kegiatan pembelajaran yang dapat membimbing siswa melakukan praktikum di laboratorium secara sistematis serta praktikum yang dapat menghasilkan produk sehingga diharapkan dapat meningkatkan pemahaman konsep dan minat kewirausahaan siswa.

c. Analisis Tugas

Pada analisis tugas dilakukan analisis KD. Berdasarkan hasil analisis KD yang terdapat dalam silabus kurikulum 2013 revisi 2016, dijabarkan menjadi beberapa indikator pembelajaran.

d. Analisis Konsep

Analisis konsep dalam penelitian ini dilakukan dengan mengidentifikasi konsep-konsep utama pada materi pembelajaran semester ganjil kelas XII.

e. Analisis Tujuan pembelajaran

Berdasarkan analisis tugas dan analisis konsep maka dapat dirumuskan tujuan pembelajaran. Analisis ini dijadikan dasar untuk mengkonstruksi penuntun praktikum yang dikembangkan.

\section{Tahap Design (Perancangan)}

Berdasarkan hasil analisis pada tahap pendefinisian, maka langkah selanjutnya adalah merancang penuntun praktikum berorientasi chemoentrepreneurship. Pada tahap ini dihasilkan draft penuntun praktikum berorientasi chemoentrepreneurship yang format penulisannya didasarkan pada buku Amri ${ }^{[15]}$ dengan sedikit modifikasi, yaitu sebagai berikut ini.

a. Cover: pada bagian ini terdapat identitas penuntun yang meliputi nama penuntun praktikum, sasaran pengguna, dan kepemilikan penuntun praktikum yang dirancang dengan warna yang menarik.

b. Tata tertib laboratorium: berisi tentang info untuk menjaga kelancaran dan keselamatan di laboratorium bagi guru dan siswa. Tata tertib terdiri atas limabagian yaitu, peralatan laboratorium, bahan kimia, aturan bekerja di laboratorium, keselamatan bekerja di laboratorium, dan penanganan limbah.

c. Pengenalan alat: berisi tentang alat yang digunakan selama praktikum beserta fungsinya yang dilengkapi dengan gambar alat tersebut.

d. Sifat dan bahaya zat kimia: berisi tentang hazard simbol. Setiap hazard simbol memuat nama, gambar, serta keterangannya.

e. Pembuatan larutan: berisi tentang cara membuat larutan dari bahan cair atau padat dengan konsentrasi tertentu.

f. Kompetensi dasar (KD) dan apersepsi: meyajikan Kompetensi Dasar yang harus dicapai siswa setelah melakukan praktikum. Apersepsi bertujuan untuk menggugah motivasi siswa.

g. Tujuan percobaan: merupakan deskripsi tentang tujuan percobaan yang akan dilakukan.

h. Mari menalar: berisi uraian singkat tentang konsep-konsep yang dicakup dalam kegiatan praktikum.

i. Menyusun hipotesis: terdiri atas pertanyaan-pertanyaan yang menuntut siswa untuk berpikir kritis dan merumuskan hipotesis.

j. Ayo buktikan hipotesismu: bagian yang memuat alat dan bahan yang diperlukan saat kegiatan praktikum.

k. Prosedur percobaan: merupakan deskripsi tentang langkah-langkah yang akan dilakukan selama kegiatan praktikum sehingga sistematis.

1. Tabel pengamatan: berisikan tabel yang dapat diisi siswa sehingga dapat membantu siswa mengorganisasikan data.

m. Mari diskusi: berisi pertanyaan-pertanyaan yang terkait dengan praktikum yang dilengkapi dengan pertanyaan bersifat chemoentrepreneurship sehingga guru dapat melihat tingkat minat siswa terhadap praktikum yang telah dilakukan.

n. Kesimpulan: berisi pertanyaan yang didesain untuk mendapatkan kesimpulan. 


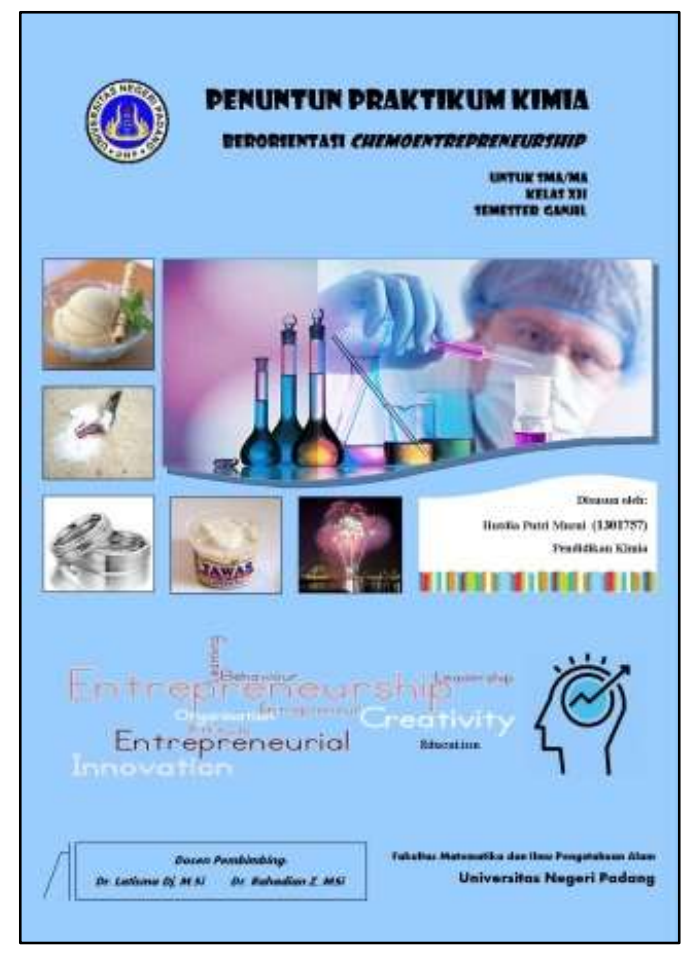

Gambar 1. Tampilan Cover

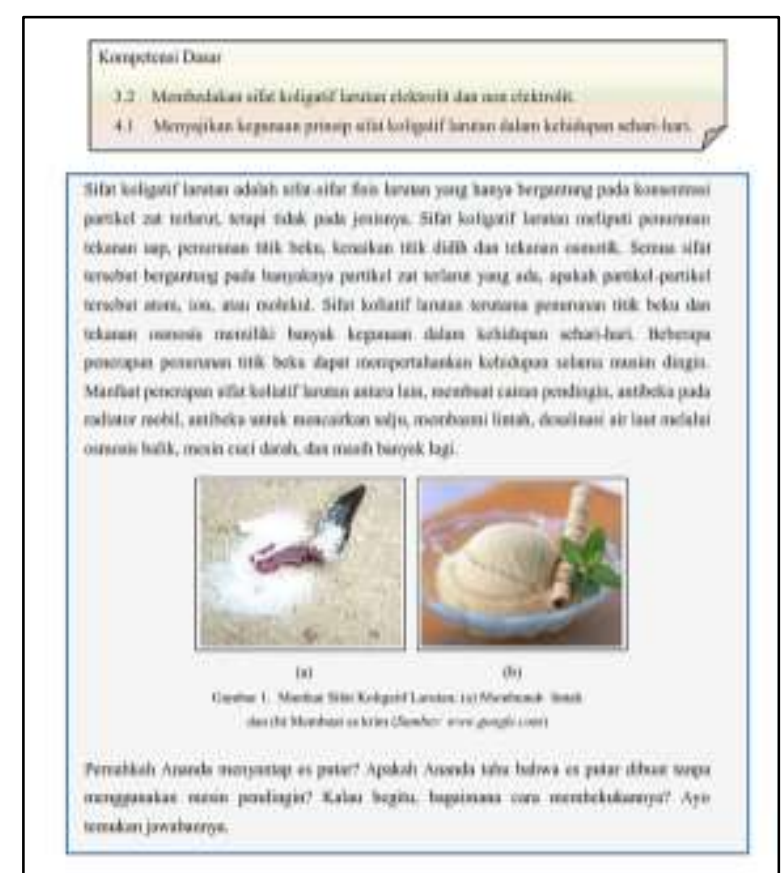

Gambar 2. Kompetensi Dasar (KD) dan Apersepsi

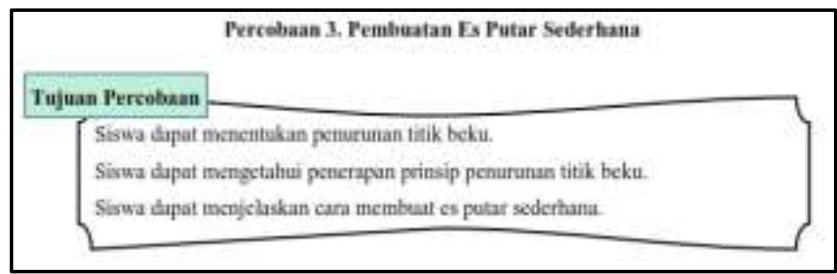

Gambar 3. Tujuan Percobaan 


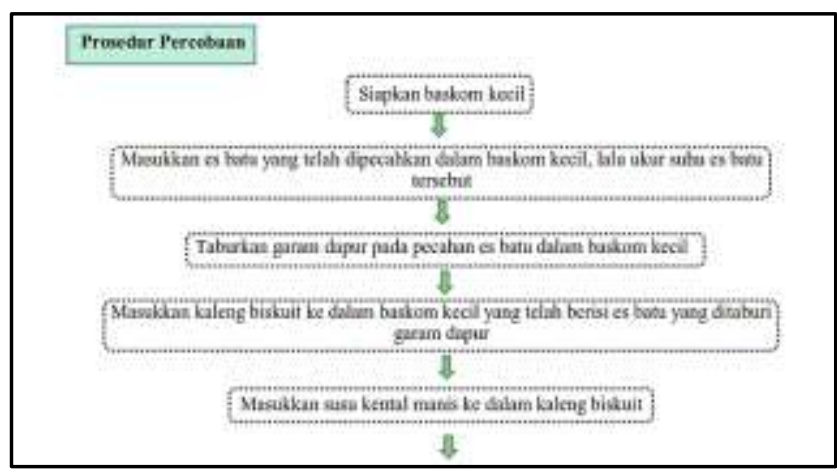

Gambar 4. Prosedur Percobaan

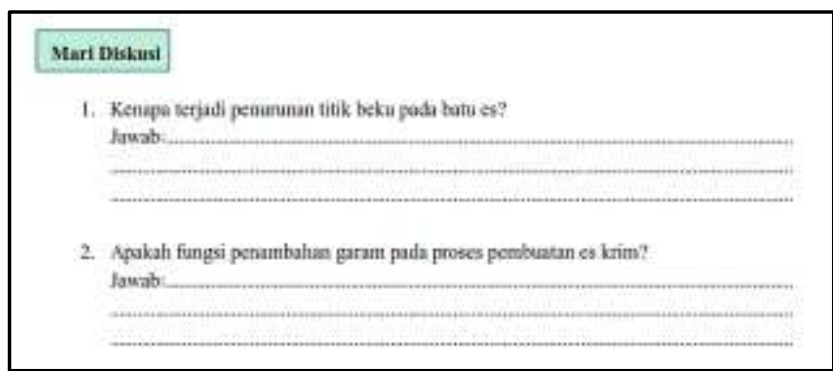

Gambar 5. Pertanyaan Diskusi

3. Tahap Develop (Pengembangan)

Tahap develop ini bertujuan untuk menghasilkan penuntun praktikum berorientasi chemoentrepreneurship untuk Kelas XII. Dalam tahap ini dilakukan penilaian oleh para ahli melalui uji validitas dan uji pengembangan produk melalui uji praktikalitas pada guru dan siswa. Revisi juga dilakukan berdasarkan masukan dari setiap tahap-tahap uji yang dilaksanakan:

a. Uji Validitas Penuntun Praktikum

Penuntun praktikum untuk Kelas XII yang telah selesai kemudian divalidasi oleh validator. Hasil validasi ahli (validator) ini dilakukan untuk mengungkapkan validitas isi, konstruk, kebahasaan dan kegrafisan.

Tabel 1. Validasi Penuntun Praktikum Berorientasi Chemoentrepreneurship

\begin{tabular}{|c|l|l|}
\hline No. & \multicolumn{1}{|c|}{ Aspek yang Dinilai } & \multicolumn{1}{|c|}{$\begin{array}{c}\text { Rata-rata Nilai } \\
\boldsymbol{k} \text { dari } \\
\text { Validator }\end{array}$} \\
\hline $\mathbf{1}$ & Validitas Isi & 0,82 \\
\hline $\mathbf{2}$ & Validitas Penyajian (konstruk) & 0,92 \\
\hline $\mathbf{3}$ & Validitas Kebahasaan & 0,90 \\
\hline $\mathbf{4}$ & Validitas Kegrafisan & 0,86 \\
\hline Nilai $\boldsymbol{k}$ Rata-rata & 0,88 \\
\hline \multicolumn{2}{|l|}{ Kategori Kevalidan } & Sangat Tinggi \\
\hline \multicolumn{2}{|l|}{ Keputusan Validator } & $\begin{array}{l}\text { Layak dengan } \\
\text { perbaikan }\end{array}$ \\
\hline
\end{tabular}

Berdasarkan di atas dinyatakan bahwa hasil uji validitas penuntun praktikum berorientasi chemoentrepreneurship untuk Kelas XII diperoleh nilai rata-rata moment kappa $(k)$ sebesar 0,88 dengan kategori kevalidan yang sangat tinggi. Walaupun kevalidan penuntun praktikum sangat tinggi, namun masih ada beberapa komponen yang harus diperbaiki.

b. Uji Praktikalitas Penuntun Praktikum

Praktikalitas penuntun praktikum berorientasi Chemoentrepreneurship dilihat dari keterpakaian produk dari hasil uji coba terbatas di lapangan menyangkut kepraktisan dan keterlaksanaan produk yang dikembangkan. Data 
praktikalitas diperoleh dari hasil analisis angket respon guru mata pelajaran kimia dan angket respon siswa yang dapat dilihat pada Grafik 1.

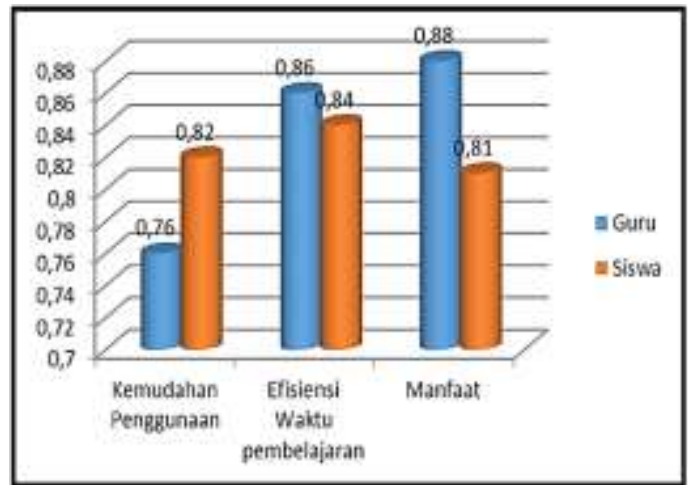

Grafik 1. Praktikalitas Penuntun Praktikum Berorientasi Chemoentrepreneurship

B. Diskusi

1. Validitas Penuntun Praktikum Berorientasi Chemoentrepreneurship untuk Kelas XII.

Validitas merupakan penilaian terhadap rancangan suatu produk. Aspek penilaian dibagi menjadi beberapa komponen yang terdiri dari kelayakan isi, komponen kebahasaan, komponen penyajian dan komponen kegrafikan ${ }^{[16]}$.

Validitas isi menunjukkan bahwa bahan ajar yang dikembangkan berdasarkan pada kurikulum atau pada rasional teoritik yang kuat ${ }^{[17]}$. Komponen kelayakan isi penuntun praktikum memiliki rata-rata momen kappa sebesar 0,82 dengan kategori kevalidan tinggi. Hal ini menunjukkan bahwa bahan ajar dalam bentuk penuntun praktikum berorientasi chemoentrepreneurship untuk kelas XII sudah sesuai dengan kompetensi dasar, sesuai dengan kemampuan siswa SMA. Penuntun praktikum dapat memberikan kesempatan pada siswa untuk dapat membuktikan teori yang sudah dipelajarinya secara langsung di laboratorium. Percobaan yang terdapat dalam penuntun praktikum juga sesuai dengan kehidupan sehari-hari sehingga dapat menambah wawasan pengetahuan siswa. Percobaan tersebut juga menghasilkan sebuah produk yang bernilai ekonomis sehingga diharapkan dapat meningkatkan minat kewirausahaan siswa.

Komponen penyajian (konstruk) memiliki rata-rata momen kappa sebesar 0,92 dengan kevalidan sangat tinggi. Hal ini menunjukkan bahwa pada bahan ajar dalam bentuk penuntun praktikum berorientasi chemoentrepreneurship untuk kelas XII sudah disusun secara sistematis.

Standar penilaian bahan ajar oleh badan standar nasional pendidikan (2006), aspek penilaian kelayakan bahasa meliputi: lugas, komunikatif, dialogis dan interaktif, dan kesesuaian dengan perkembangan peserta didik. Komponen kelayakan kebahasaan penuntun praktikum memiliki momen kappa sebesar 0,90 dengan kategori kevalidan tinggi. Hal ini menunjukkan bahwa penuntun praktikum berorientasi chemoentrepreneurship untuk kelas XII telah lugas, komunikatif, dialogis dan interaktif karena memiliki bentuk dan ukuran huruf yang dapat dibaca. Penuntun praktikum juga menggunakan kaidah bahasa Indonesia yang jelas, sederhana dan mudah dipahami.

Standar penilaian bahan ajar oleh badan standar nasional pendidikan (2006), aspek penilaian kelayakan kegrafikan meliputi : uraian penuntun praktikum, desain kulit penuntun praktikum, dan desain isi penuntun praktikum yang dapat memotivasi siswa untuk belajar. Komponen kegrafikan memiliki rata-rata momen kappa sebesar 0,86 dengan kategori kevalidan sangat tinggi. Hal ini menunjukkan bahwa penuntun praktikum berorientasi chemoentrepreneurship untuk Kelas XII telah memiliki jenis dan ukuran huruf yang menarik serta penampilan grafis dan desain yang menarik.

Secara keseleluruhan, validitas modul tiap komponen sangat tinggi. Momen kappa komponen isi, penyajian, kebahasaan dan kegrafisan berturut-turut adalah $0,82,0,92,0,90$, dan 0,86 dengan rata-rata 0,88 dengan kategori kevalidan sangat tinggi. Hal ini menunjukkan bahwa penuntun praktikum berorientasi chemoentrepreneurship untuk kelas XII telah sesuai dengan komponen-komponennya. Validitas penuntun praktikum berorientasi chemoentrepreneurship untuk kelas XII telah tinggi, namun perlu dilakukan revisi sesuia saran-saran validator. Setelah dilakukan revisi terhadap penuntun praktikum, kemudian dilakukan uji praktikalitas.

2. Praktikalitas Penuntun Praktikum Berorientasi Chemoentrepreneurship untuk Kelas XII

Praktikalitas diukur dengan cara memberikan lembar praktikalitas kepada guru dan siswa. Lembar praktikalitas guru terdiri dari 12 penilaian yang terdiri dari kemudahan penggunaan, efisiensi waktu pembelajaran dan manfat penggunaan penuntun praktikum. Hasil lembar praktikalitas guru dan siswa dianalisis menggunakan momen kappa $(k)$ untuk mengungkapkan kepraktisan penuntun praktikum berorientasi chemoentrepreneurship untuk Kelas XII.

Rata-rata momen kappa dari lembar angket respon guru sebesar 0,82 dengan kategori sangat tinggi (sangat praktis). Suatu bahan ajar yang dikatakan praktis jika bahan ajar tersebut dapat dan mudah digunakan dan ditafsirkan ${ }^{[18]}$. Hal ini menunjukkan bahwa penuntun praktikum berorientasi chemoentrepreneurship mudah dan praktis digunakan guru. Dengan menggunakan penuntun praktikum waktu saat kegiatan praktikum lebih efisien . Uji praktikalitas dilakukan oleh siswa kelas XII SMAN 12 Padang yang berjumlah 27. Berdasarkan Tabel 10, rata-rata momen kappa 
dari hasil lembar praktikalitas siswa sebesar 0,82 dengan kategori kepraktisan sangat tingi (sangat praktis). Selain itu, siswa juga dapat menjawab pertanyaan pada bagian mari diskusi yang ada pada penuntun praktikum berorientasi chemoentrepreneurship untuk Kelas XII.

Berdasarkan hal diatas dapat disimpulkan bahwa penuntun praktikum berorientasi chemoentrepreneurship untuk Kelas XII dapat membantu siswa dalam kegiatan pembelajaran di laboratorium pada saat praktikum kimia, membantu siswa dalam meningkatkan pengetahuan, keterampilan dan dapat meningkatkan minat kewirausahaan siswa sehingga siswa dapat mengembangkan potensi dirinya setelah menyelesaikan pendidikan/ lulus SMA/MA.

\section{KESIMPULAN}

Berdasarkan penelitian yang telah dilakukan, dapat disimpulkan sebagai berikut ini.

1. Dihasilkan penuntun praktikum berorientasi chemoentrepreneurship untuk SMA/MA Kelas XII yang dikembangkan menggunakan model pengembangan 4D dengan tiga tahap, yaitu tahap pendefinisian (define), tahap perancangan (design) dan tahap pengembangan (develop).

2. Penuntun praktikum berorientasi chemoentrepreneurship untuk SMA/MA Kelas XII yang dihasilkan mempunyai kategori kevalidan dan kepraktisan sangat tinggi, sehingga penuntun praktikum berorientasi chemoentrepreneurship untuk SMA/MA kelas XII semester ganjil dapat digunakan dalam pembelajaran di laboratorium siswa SMA/MA kelas XII.

\section{UCAPAN TERIMAKASIH}

Penulis mengucapkan terimakasih kepada Ibu Dr. Latisma Dj, M.Si, Bapak Dr. Rahadian Z, M.Si, Ibu Dra. Iryani, M.S, Ibu Guspatni, S.Pd, M.A, Bapak Edi Nasra, S.Si, M.Si, Ibu Dra. Syamsi Aini, M.Si, Ph.D, serta semua pihak yang telah membantu dalam penyelesaian penelitian dan penyusunan artikel ini.

\section{REFERENSI}

[1] Undang-Undang Republik Indonesia No.20 Tahun 2003. Sistem Pendidikan Nasional. Jakarta: Departemen Pendidikan Nasional.

[2] Baswedan, Anies. 2015. Meneropong Jalan Masa Depan Luluan SMA Sederajat. (online di http://www2.jawapos.com/baca/artikel/17442/Meneropong-Jalan-Masa-Depan-Lulusan-SMA-Sederajat, diakses pada 2 Oktober 2016).

[3] Badan Pusat Statistik. 2016. Jumlah Angkatan Kerja, Penduduk Bekerja, Pengangguran, TPAK dan TPT. Jakarta (online di www.bps.go.id, diakses pada tanggal 26 September 2016).

[4] Instruksi Presiden Republik Indonesia No.4 Tahun 1995. Gerakan Nasional Memasyarakatkan dan Membudayakan Kewirausahaan. Jakarta: Badan Perencanaan Pembangunan Nasional.

[5] Wijayati, Nanik and Wara Dyah. 2009. "Implementation of Chemo-entrepreneurship Teaching Approach for Improving Student's Life Skills. Jurnal Ilmu Pendidikan, Vol. 16, No. 2: 100-105.

[6] American Chemical Society Committee on Education. 2012. ACS Guidelines and Recommendations for the Teaching of High School Chemistry. Washington, DC: The American Chemical Society.

[7] Kemendikas No.36/D/O/. 2001. Petunjuk Teknis Pelaksanaan Penilaian Angka Kredit Jabatan Dosen. Jakarta: Departemen Pendidikan Nasional.

[8] Supartono, dkk. 2009. "Pembelajaran Kimia Menggunakan Kolaborasi Konstruktif dan Inkuiri Berorientasi ChemoEntrepreneurship". Jurnal Inovasi Pendidikan Kimia, Vol. 2, No. 3, 476-483.

[9] Qudsiyah, dkk. 2013. "Implementasi Praktikum Aplikatif Berorientasi Chemoentrepreneurship (CEP) terhadap Peningkatan Hasil Belajar Kimia”. Jurnal Inovasi Pendidikan Kimia, Vol. 8, No. 1, 1309-1318.

[10] Masithoh, Ita. 2015. "Pengembangan Modul Larutan Penyangga Berorientasi Chemoentrepreneurship (CEP) Kelas XI SMA/MA". Skripsi. Semarang: Universitas Semarang.

[11] Sumarti, et al. 2014. "Material Module Development of Colloid Orienting on Local-Advantage-Based ChemoEntrepreneurship to Improve Students' Soft Skill”. International Journal of Humanities and Management Sciences (IJHMS), Vol. 2, Issue. 2, 42-46. 
[12] Boslaugh, Sarah dan Paul A. W. 2008. Statistics in a Nutshell, a desktop quick reference. Beijing, Cambridge, Famham, Köln, Sebastopol, Taipei, Tokyo: O'reilly.

[13] Trianto. 2010. Model Pembelajaran Terpadu. Jakarta: Bumi Aksara.

[14] Monica, Laura Christina Luzar. 2011. "Efek Warna dalam Dunia Desain dan Periklanan”. Jurnal: Humaniora. Vol.2 No.2: 1084-1096.

[15] Amri, Sofan. 2013. Pengembangan \& Model Pembelajaran dalam Kurikulum 2013. Jakarta: Prestasi Pustaka Publisher.

[16] Departemen Pendidikan Nasional. 2008. Pengembangan Bahan Ajar. Jakarta: Departemen Pendidikan Nasional, Direktorat Jenderal Manajemen Pendidikan Dasar dan Menengah, Direktorat Pembinaan Sekolah Menengah Atas.

[17] Rochmad. 2012. "Desain Model Pengembangan Perangkat Pembelajaran Matematika". Jurusan Matematika FMIPA UNNES, Vol. 3, No. 1, 59-72

[18] Mudjijo. 1995. Tes Hasil Belajar. Jakarta: Bumi Aksara. 
